\title{
Detecting Runoff Variation of the Mainstream in Weihe River
}

\author{
Qiang Huang and Jingjing Fan \\ Xian University of Technology, Xian 710048, China \\ Correspondence should be addressed to Qiang Huang; wresh@mail.xaut.edu.cn
}

Received 23 August 2013; Accepted 16 October 2013

Academic Editor: G. H. Huang

Copyright (C) 2013 Q. Huang and J. Fan. This is an open access article distributed under the Creative Commons Attribution License, which permits unrestricted use, distribution, and reproduction in any medium, provided the original work is properly cited.

\begin{abstract}
The runoff change in Weihe River is significantly decreasing with the climate change and the huge increasing of human activities. The analysis of the variation changes of runoff would provide scientific understanding of Weihe River basin and similar basins. Mann-Kendall method is used to detect the variation changes of annual and seasonal runoff of 1919-2011 at the outlet station, that is, Huaxian station, in the mainstream of Weihe River. The results show that the runoff variation point is 1990, and there were significant changes in trends and periodicals, corroborated by wavelet variance analysis, Kendall's rank tests, and trends persistence test, in annual, seasonal, and monthly runoff at the variation point of 1990. Attribution analysis indicates that the primary drivers of the shift in runoff variation were human activities rather than climate change, as water consumption (particularly groundwater consumption) increased sharply in the 1990s.
\end{abstract}

\section{Introduction}

In recent decades, there are significantly changes in climate, such as temperature, precipitation, and hydrology as runoff, flood and drought. Runoff volumes in a catchment are influenced by numerous factors, like climatic variables (particularly precipitation), human activities, subsurface drainage patterns, and various other geographical and hydrological variables [1-3]. With the changing of the factors, runoff changes significantly. Many aspects of the Earth's climate system have changed abruptly and further variations are predicted $[4,5]$. Runoff in catchments of various regions is changing [6]. Notably, the runoff is declining in catchments of the Haihe River [7], Yellow River [8], Liaohe River, and Yangtze River [9].

The sequential Mann-Kendall test is a statistical test that has been used (e.g., [1, 7]) in detecting variation changes in runoff volumes and many other variables. This test, initially developed by Mann [10] and modified by Kendall [11], is straightforward, robust, and can handle both missing values and values below detection limits [12-14]. It is recommended as a standard method for detecting variation changes in serially independent hydrological data $[15,16]$. Using the MannKendall method, Yang and Tian [7] found that variations in runoff in the Haihe River basin occurred in the period of 1978-1985. Zhang et al. [17] found that the sediment and runoff in Yangtze River basin have a significant change in 1980s.

In this paper, the variation in Weihe River is analyzed using the sequential Mann-Kendall test method. It examines both seasonal and annual trends, using data obtained from the Huaxian hydrological station. A variation at around 1990 is then corroborated by wavelet variance analysis, which is used to detect changes in runoff periodicity [18-22], Kendall's rank test (a nonparametric method for detecting or testing trends), and rescaled range analysis (a nonlinear technique for evaluating the persistence of apparent trends), which are widely used in hydrology (e.g., [23-28]). Finally, we explore the probable causes of the shift in runoff by the analysis of attribution [29], focusing on the factors that contribute to reductions in precipitation and increases in human water consumption in the Weihe River catchment.

\section{Methodology}

The sequential Mann-Kendall test $[10,30]$ is used to detect variation changes in runoff (annual, seasonal, and monthly) from 1919 to 2011 at the Huaxian hydrological station. In this test, the null hypothesis is that a series of observations of a variable $\tau_{i}$ (where $i=1, \ldots, n$ ) are independent and 


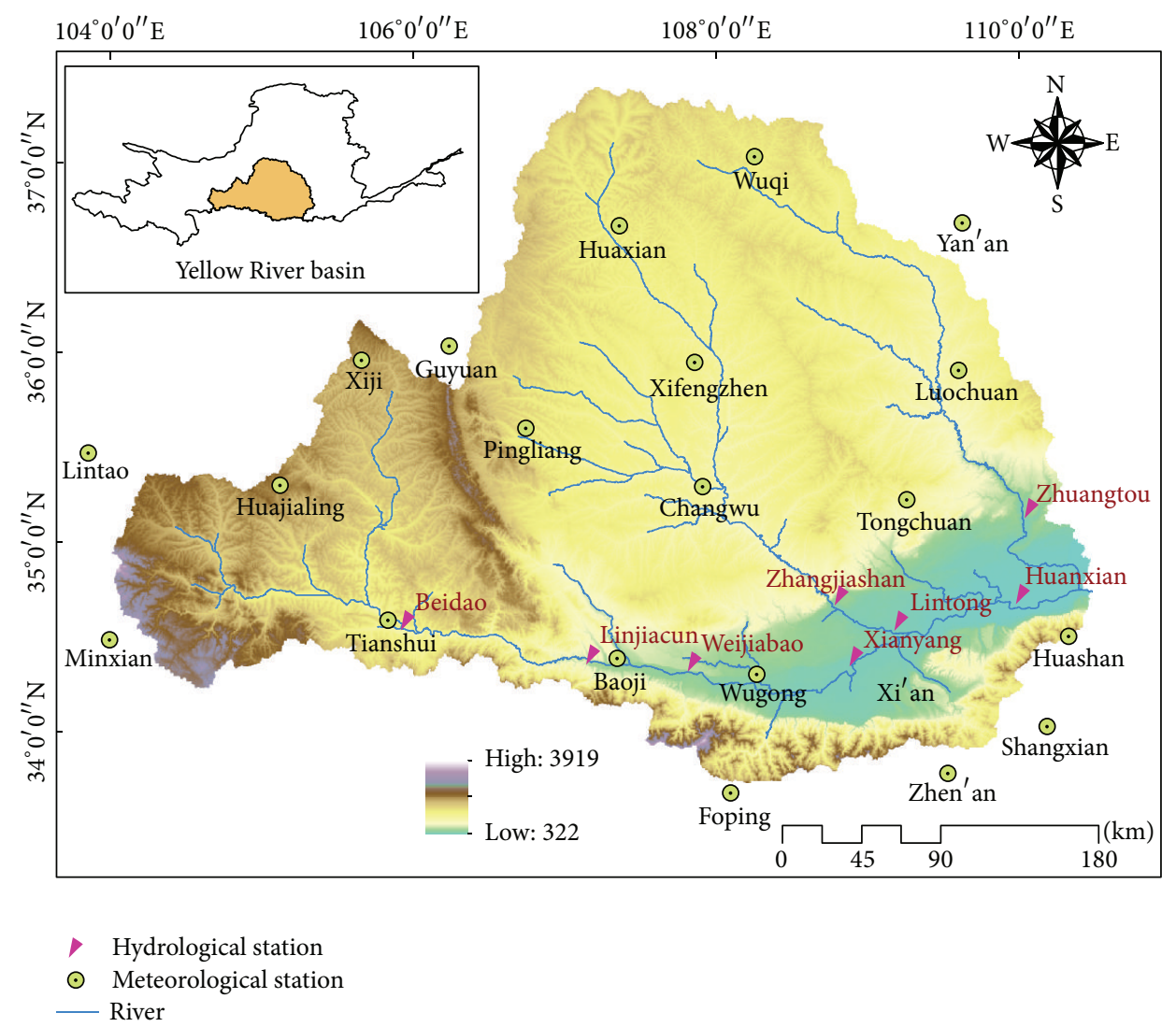

Figure 1: Map of the River Wei Basin.

identically distributed. The alternative hypothesis is that there is a monotonic trend in $\tau_{i}$. The Mann-Kendall test statistic, $D_{\tau}$, is calculated here using the following model:

$$
D_{\tau}=\sum_{i=1}^{\tau} R_{i} \quad(\tau=2,3, \ldots, i),
$$

where

$$
R_{i}=\left\{\begin{array}{ll}
+1, & x_{i}>x_{j} \\
0, & x_{i} \leq x_{j}
\end{array} \quad(j=1,2, \ldots, i)\right.
$$

$R_{i}$ is normally distributed with a mean and variance given by (3) and (4), respectively:

$$
\begin{gathered}
E\left(D_{\tau}\right)=\frac{\tau(\tau-1)}{4}, \\
V\left(D_{\tau}\right)=\frac{\tau(\tau-1)(2 \tau+5)}{72} .
\end{gathered}
$$

Sequential values of a statistic, $U F_{\tau}$ (for which $U F_{1}=0$ ), are now calculated from

$$
U F_{\tau}=\frac{\left|D_{\tau}-E\left(D_{\tau}\right)\right|}{\sqrt{V\left(D_{\tau}\right)}} .
$$

The data series is then reversed, and values corresponding to $U F_{\tau}\left(U B_{\tau}=-U F_{\tau} ; \tau=n, n-1, \ldots, 1\right.$ and $\left.U B_{1}=0\right)$ are calculated.
If the two sequences are accepted at a defined probability level, $\alpha$, then $\left|U F_{\tau}\right|<U F_{1-\alpha / 2}$, where $U F_{1-\alpha / 2}$ is the critical value of a standard normal distribution for a probability exceeding $\alpha / 2$.

A positive $U F_{\tau}$ or $U B_{\tau}$ value indicates an upward trend, and negative values indicate a downward trend in variable $\tau$ with time. Further, if $U F_{\tau}$ or $U B_{\tau}>U F_{1-\alpha / 2}$ there is a significant upward trend, while $U F_{\tau}$ or $U B_{\tau}<U F_{1-\alpha / 2}$ indicates a significant downward trend.

In this study, $\alpha$ is set at $P<0.05$. The sequential MannKendall test enables detection of the approximate time of changes in trends from intersections of the forward and backward curves of the test statistic. If the intersection point is significant at $\alpha=0.05$, then the critical point of change is at that point [31]. Hence, the Mann-Kendall test provides an efficient method for pinpointing the starting times of trends [7].

\section{Study Area and Data}

3.1. Study Area. The Weihe River rises in the Niaoshu hill, in Gansu province, and flows into the Yellow River in Shaanxi province. Its catchment covers 132 million $\mathrm{km}^{2}\left(107^{\circ} 39^{\prime}-\right.$ $108^{\circ} 37^{\prime} \mathrm{E}$ to $33^{\circ} 42^{\prime}-34^{\circ} 14^{\prime} \mathrm{N}$; Figure 1 ), and the mean annual streamflow amounted to 7.53 billion $\mathrm{m}^{3}$ (equivalent to an annual runoff depth of $572 \mathrm{~mm} /$ year) from 1951 to 2011 . Huaxian station $\left(34^{\circ} 35^{\prime} \mathrm{E}, 109^{\circ} 42^{\prime} \mathrm{N}\right)$ is an important hydrological 


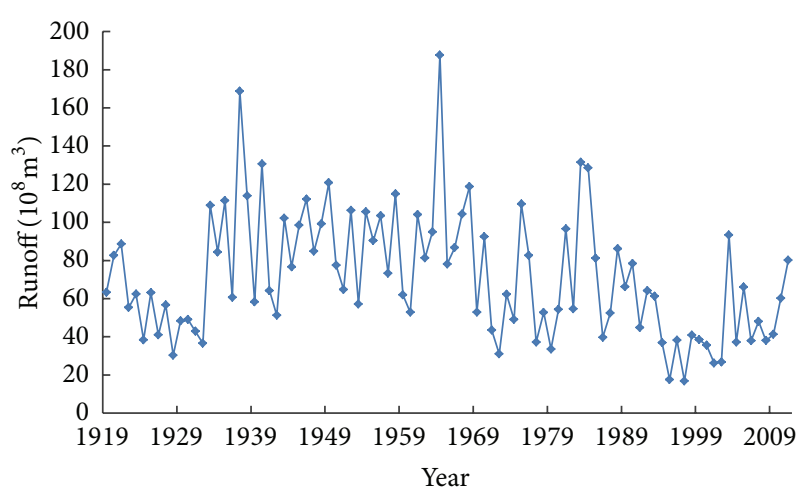

FIgURE 2: Annual runoff volumes in the Weihe River at the Huaxian hydrological station from 1919 to 2011.

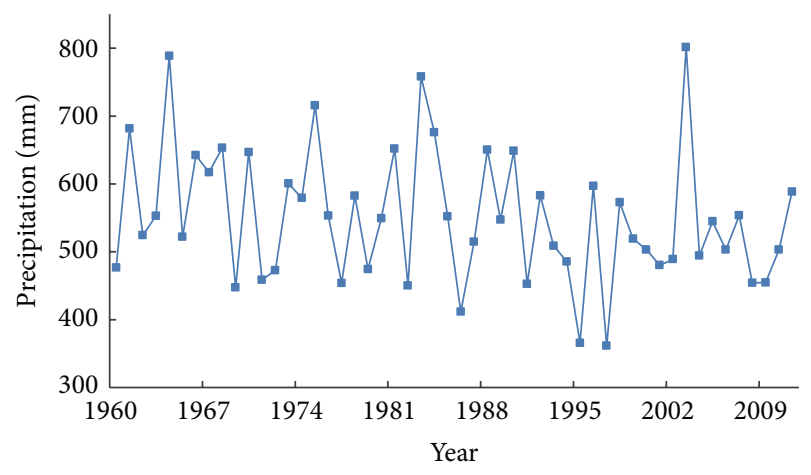

FIGURE 3: Estimated annual precipitation in the Weihe River basin from 1956 to 2011.

station, which monitors the flow from 105.3 million $\mathrm{km}^{2}$ of the catchment, that is, $81 \%$ of the total Weihe River basin area. It was established in 1919 and is the closest station to the confluence with the Yellow River. Mean annual streamflow is approximately 7.14 billion $\mathrm{m}^{3}$ from 1951 to 2011 , and mean annual precipitation is $512 \mathrm{~mm}$. However, the streamflow is distinctly seasonal and substantially higher in the period from July to October than in the following period from November to June of the next year.

3.2. Data. Monthly mainstream runoff data collected at Huaxian hydrological station from January 1919 to December 2011 (Figure 2) were obtained from the records. Monthly precipitation data from January 1956 to December 2011, collected from 18 monitoring stations in the Weihe River basin, were obtained from the Chinese meteorological data sharing system. Locations of the Huaxian hydrological station and rain gauging stations are shown in Figure 1 and Table 1. The annual areal precipitation of Weihe River basin (Figure 3) was calculated from the area-weighted monthly precipitation data collected at the 18 rain gauging stations.

\section{Results and Discussion}

4.1. Annual Runoff Test. The sequential Mann-Kendall test is used to diagnose the variations in annual, seasonal, and

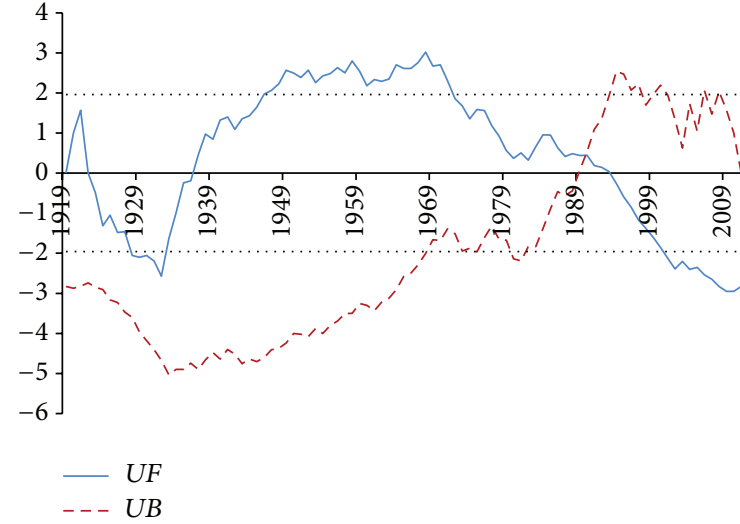

FIgURE 4: Mann-Kendall test statistics (UF and $U B$ values) calculated from annual runoff data at the Huaxian station.

monthly runoff data obtained from the Huaxian station for the sequence from 1919 to 2011. Values of $U F$ and $U B$ sequence calculated from the annual runoff data show that runoff in the Weihe River basin significantly declined during the study period. The point of intersection of the $U F$ and $U B$ curves indicates that the variation of annual runoff began in 1990 (Figure 4), that of spring runoff (1 March-31 May) began in 1999, that of summer runoff (1 June-31 August) began in 1990, that of autumn runoff (1 September-31 November) began in 1989, that of winter runoff (1 December-28 January) began in 1977, that of wet season runoff (1 July-31 October) began in 1990, and that of dry season runoff (without wet season in a year) began in 1991 (Figure 5). Figures 4 and 5 show that annual runoff trend is similar to autumn wet and dry season. So, according to the results, 1990 is chosen as variation of the whole catchment. The result is similar to that of the previous study in the same area. Bai and Zhang [32] found that there are variation points in 1990s by using the rank sum test.

\subsection{Basic Law Changes at Variation Point}

4.2.1. Mean Changes. Aiming to verify the variation changes, mean change is an important factor. As the sequential MannKendall test results show, 1990 is the year of the variation beginning time, so 1990 is chosen as a demarcation point. The sequence was divided into two parts, one is the former (19191989) and another is the latter (1990-2011). The identified time of the variation in the annual runoff is verified by a marked difference in mean values in the periods before and after it, which amounted to 8.74 billion $\mathrm{m}^{3}$ before 1990 and 4.67 billion $\mathrm{m}^{3}$ from 1990 to 2011, a decrease of $41 \%$.

In order to analyze the seasonal variation changes in runoff in more detail, the time series can be divided into five periods: 1919-1969 (selected as a baseline), 1970-1979, 1980-1989, 1990-1999, and 2000-2011. Runoff values for each month during each of the periods are shown in Table 2. The data clearly show that the flow declined relative to the baseline period in all subsequent periods, particularly in 1990-1999 and 2000-2011, when the runoff volumes were lower than $50 \%$ compared to the baseline volumes in seven months. 
TABLE 1: Locations of the 18 rain gauging stations that provided the precipitation data examined in this study.

\begin{tabular}{|c|c|c|c|c|c|}
\hline Station no. & Station name & Province & Latitude $(\mathrm{N})$ & Longitude (E) & Elevation $(\mathrm{m})$ \\
\hline 52986 & Lintao & Gansu & $35 / 21$ & $103 / 51$ & 1893.8 \\
\hline 52996 & Huajialing & Gansu & $35 / 23$ & $105 / 00$ & 2450.6 \\
\hline 53817 & Guyuan & Ningxia & $36 / 00$ & $106 / 16$ & 1753.0 \\
\hline 53821 & Huanxian & Gansu & $36 / 35$ & $107 / 18$ & 1255.6 \\
\hline 53903 & Xiji & Ningxia & $35 / 58$ & $105 / 43$ & 1916.5 \\
\hline 53915 & Pingliang & Gansu & $35 / 33$ & $106 / 40$ & 1346.6 \\
\hline 53923 & Xifengzhen & Gansu & $35 / 44$ & $107 / 38$ & 1421.0 \\
\hline 53929 & Changwu & Shaanxi & $35 / 12$ & $107 / 48$ & 1206.5 \\
\hline 53947 & Tongchuan & Shaanxi & $35 / 05$ & $109 / 04$ & 978.9 \\
\hline 56093 & Minxian & Gansu & $34 / 26$ & $104 / 01$ & 2315.0 \\
\hline 57006 & Tianshui & Gansu & $34 / 35$ & $105 / 45$ & 1141.7 \\
\hline 57016 & Baoji & Shaanxi & $34 / 21$ & $107 / 08$ & 612.4 \\
\hline 57034 & Wugong & Shaanxi & $34 / 15$ & $108 / 13$ & 447.8 \\
\hline 57036 & Xian & Shaanxi & $34 / 18$ & $108 / 56$ & 397.5 \\
\hline 57046 & Huashan & Shaanxi & $34 / 29$ & $110 / 05$ & 2064.9 \\
\hline 57134 & Foping & Shaanxi & $33 / 31$ & $107 / 59$ & 827.2 \\
\hline 57144 & Zhen'an & Shaanxi & $33 / 26$ & $109 / 09$ & 693.7 \\
\hline 57143 & Shangzhou & Shaanxi & $33 / 52$ & $109 / 58$ & 742.2 \\
\hline
\end{tabular}

TABLE 2: Monthly runoff volumes during the five subperiods $\left(10^{8} \mathrm{~m}^{3}\right)$ and changes relative to baseline (1919-1969) values.

\begin{tabular}{|c|c|c|c|c|c|c|c|c|c|c|c|c|c|}
\hline \multirow{2}{*}{$\begin{array}{l}\text { Year } \\
\text { Month }\end{array}$} & \multirow{2}{*}{$\begin{array}{c}\text { 1919-1969 } \\
\text { Mean }\end{array}$} & \multicolumn{3}{|c|}{ 1970-1979 } & \multicolumn{3}{|c|}{ 1980-1989 } & \multicolumn{3}{|c|}{ 1990-1999 } & \multicolumn{3}{|c|}{ 2000-2011 } \\
\hline & & Mean & $\begin{array}{l}\text { Mean } \\
\text { change }\end{array}$ & $\begin{array}{l}\text { Percent } \\
\text { change }\end{array}$ & Mean & $\begin{array}{l}\text { Mean } \\
\text { change }\end{array}$ & $\begin{array}{l}\text { Percent } \\
\text { change }\end{array}$ & Mean & $\begin{array}{l}\text { Mean } \\
\text { change }\end{array}$ & $\begin{array}{l}\text { Percent } \\
\text { change }\end{array}$ & Mean $/ 10^{8} \mathrm{~m}^{3} / \mathrm{s}$ & $\begin{array}{l}\text { Mean } \\
\text { change }\end{array}$ & $\begin{array}{l}\text { Percent } \\
\text { change }\end{array}$ \\
\hline January & 2.36 & 1.21 & -1.16 & $-48.9 \%$ & 1.52 & -0.85 & $-35.8 \%$ & 1.06 & -1.30 & $-55.1 \%$ & 1.54 & -0.82 & $-34.8 \%$ \\
\hline February & 2.37 & 1.39 & -0.97 & $-41.1 \%$ & 1.61 & -0.76 & $-32.0 \%$ & 1.18 & -1.19 & $-50.2 \%$ & 1.37 & -1.00 & $-42.3 \%$ \\
\hline March & 3.28 & 1.78 & -1.50 & $-45.8 \%$ & 2.04 & -1.23 & $-37.6 \%$ & 2.07 & -1.21 & $-36.9 \%$ & 1.50 & -1.77 & $-54.1 \%$ \\
\hline April & 4.53 & 3.17 & -1.36 & $-29.9 \%$ & 3.62 & -0.91 & $-20.1 \%$ & 3.32 & -1.21 & $-26.8 \%$ & 1.79 & -2.74 & $-60.6 \%$ \\
\hline May & 5.66 & 5.26 & -0.40 & $-7.0 \%$ & 5.86 & 0.20 & $3.6 \%$ & 4.12 & -1.54 & $-27.1 \%$ & 2.39 & -3.26 & $-57.7 \%$ \\
\hline June & 5.09 & 2.38 & -2.71 & $-53.2 \%$ & 6.25 & 1.16 & $22.9 \%$ & 4.05 & -1.04 & $-20.4 \%$ & 2.33 & -2.76 & $-54.2 \%$ \\
\hline July & 12.17 & 7.21 & -4.95 & $-40.7 \%$ & 11.58 & -0.58 & $-4.8 \%$ & 7.57 & -4.59 & $-37.7 \%$ & 4.11 & -8.06 & $-66.3 \%$ \\
\hline August & 13.74 & 7.37 & -6.37 & $-46.3 \%$ & 13.11 & -0.63 & $-4.6 \%$ & 6.64 & -7.09 & $-51.6 \%$ & 7.10 & -6.63 & $-48.3 \%$ \\
\hline September & 14.15 & 12.73 & -1.42 & $-10.0 \%$ & 15.89 & 1.73 & $12.3 \%$ & 5.36 & -8.79 & $-62.1 \%$ & 10.58 & -3.57 & $-25.3 \%$ \\
\hline October & 10.73 & 10.65 & -0.08 & $-0.7 \%$ & 10.67 & -0.06 & $-0.6 \%$ & 4.63 & -6.11 & $-56.9 \%$ & 10.17 & -0.57 & $-5.3 \%$ \\
\hline November & 5.62 & 4.69 & -0.93 & $-16.6 \%$ & 5.14 & -0.48 & $-8.5 \%$ & 2.77 & -2.85 & $-50.6 \%$ & 4.12 & -1.50 & $-26.6 \%$ \\
\hline December & 3.10 & 1.63 & -1.47 & $-47.5 \%$ & 1.87 & -1.23 & $-39.6 \%$ & 1.01 & -2.09 & $-67.3 \%$ & 2.23 & -0.87 & $-28.0 \%$ \\
\hline
\end{tabular}

The most pronounced decline was during July in the most recent period (2000-2011), when the mean runoff volume was just 0.411 billion $\mathrm{m}^{3}$, compared to the baseline volume of 1.217 billion $\mathrm{m}^{3}$, a drop of $66.3 \%$. In the second period (19701979), there is only one percent volumes above $50 \%$, and 6 are before $40 \%$, the high percent shows that it has an obviously change in the period. The main reason for the significant decline of runoff volumes is that there is a huge numbers of human activities happened in the periods. These findings confirm that the runoff variation changed substantially in the 1990s.

4.2.2. Periodicity Changes. Wavelet variance analysis is one of several methods based on wavelet functions that have been developed and applied to detect changes in the periodicity of cycles of the data collected from hydrological system [1822]. Application of this method, using equations presented by, clearly show that there were substantial reductions in annual runoff, the periodicity of two sequences. One is before variation point (1919-1989), and the other is after (1919-2011). Figure 6 shows that the before sequence has 18 and 37 years period and the after sequence has 7,17 , and 45 years. Because of the dramatically change after variation, the total has a short period. These results further corroborate the variation in runoff trends detected at around 1990.

4.2.3. Trends and Persistence Changes. As mentioned in the introduction, Kendall's rank test is a nonparametric method 


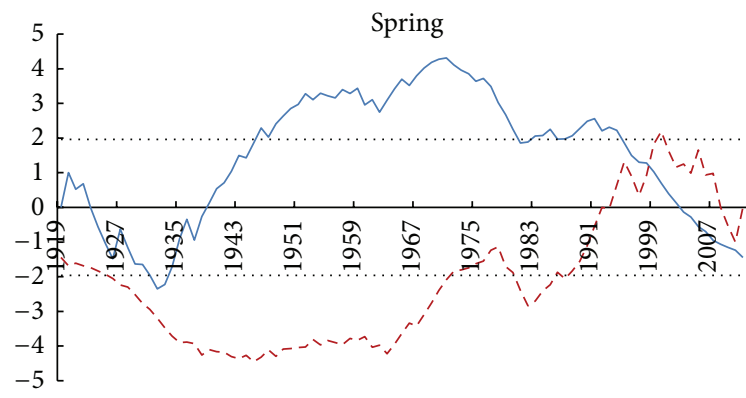

(a)

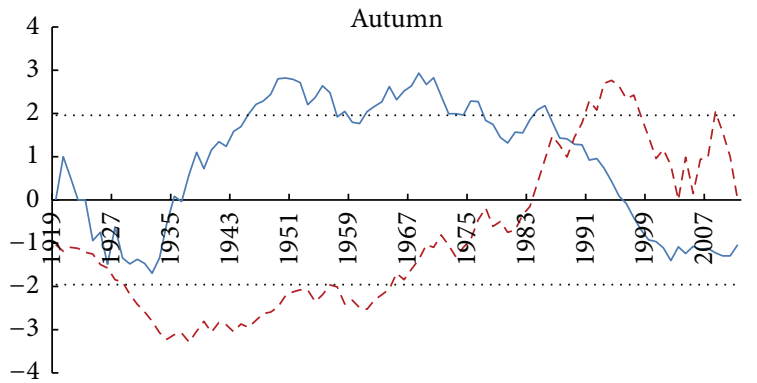

(c)

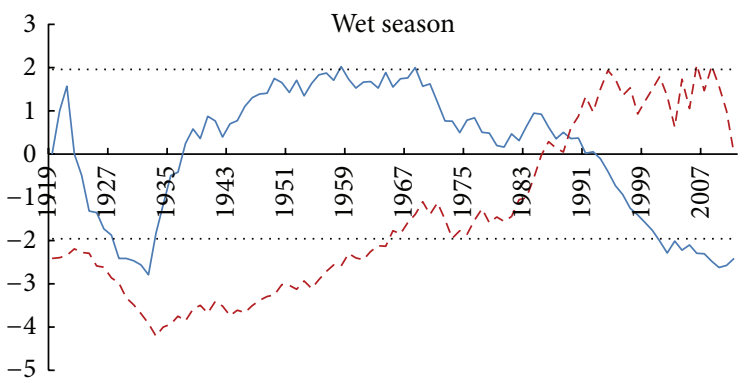

(e)

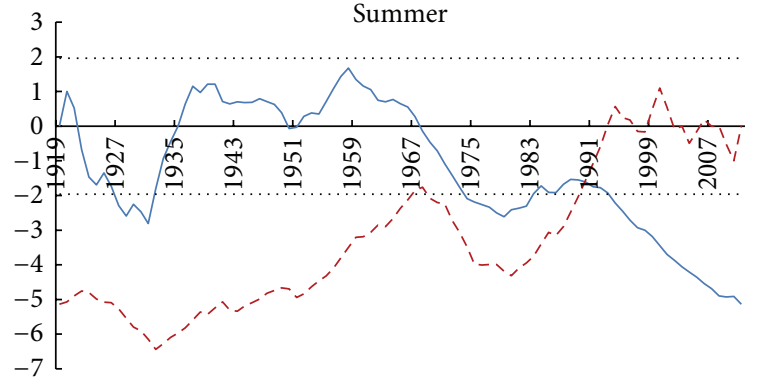

(b)

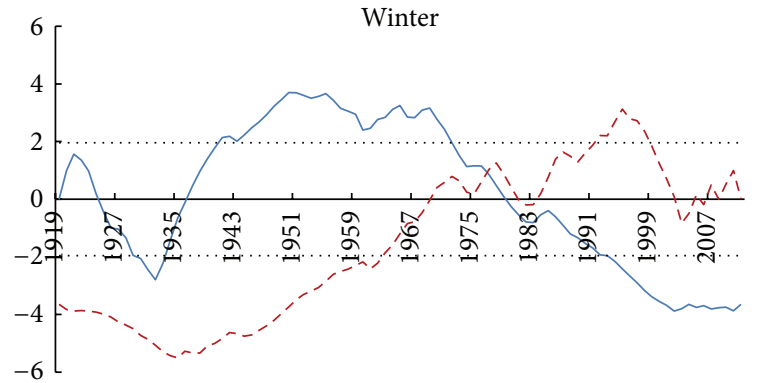

(d)

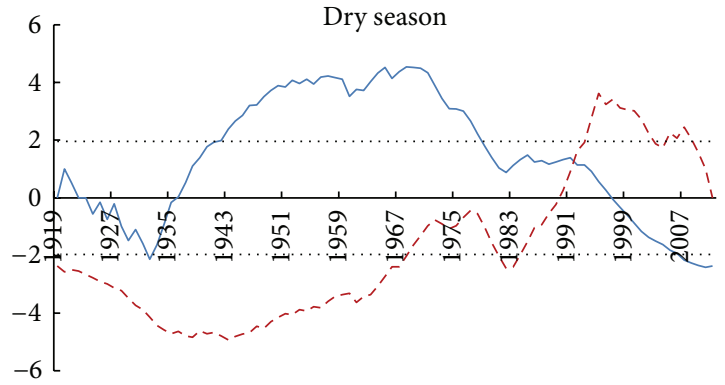

(f)

FigURE 5: Mann-Kendall test statistics ( $U F$ and $U B$ values) calculated from seasonal runoff data at the Huaxian station.

for detecting or testing trends, and rescaled range analysis is a nonlinear technique for evaluating the persistence of apparent trends, both of which are widely used in hydrology (e.g., [23-28]). Application of Kendall's rank test to explore further the trend changes clearly shows that there was a highly significant $(P<0.001)$ decline in runoff during the entire study period from 1919 to 2011, although there was a slight (nonsignificant) increase in the years before 1989 (Table 3). Furthermore, Hurst values [23], obtained from rescaled range analysis $(R / S)$, for the former series 1919 1989, have a slight (nonsignificant) increase, and positive persistence. Because of the dramatical change after the variation, the total trend is decline, but after the variation is increase. They all have positive persistence, but the total one is smaller.

4.2.4. Hydrological Parameters Changes. Key parameters for assessing changes in river runoff are the coefficient of variation $(\mathrm{Cv})$ and skewness (Cs). Changes in these hydrological parameters during the study period are shown in Table 4. The data show that $\mathrm{Cv}$ slightly increased from 0.405 to 0.456
TABLE 3: Results of runoff trend and persistence tests of 1919-1989 and 1990-2011 (throughout the study period).

\begin{tabular}{lcc}
\hline & $1919-1989$ & $1919-2011$ \\
\hline \multirow{2}{*}{ Trends } & 0.442 & -2.828 \\
& Insignificantly upward & Significantly downward \\
\hline \multirow{2}{*}{ Persistence } & 0.978 & 0.762 \\
& Positive & Positive \\
\hline
\end{tabular}

TABLE 4: Coefficients of variation (Cv) and skewness (Cs) of annual runoff volumes of 1919-1989, 1919-2011 (the whole study period).

\begin{tabular}{lcc}
\hline & $1919-1989$ & $1919-2011$ \\
\hline $\mathrm{Cv}$ & 0.405 & 0.456 \\
$\mathrm{Cs}$ & 0.802 & 0.841
\end{tabular}

between 1919-1989 and 1919-2011, while Cs significantly fell from 0.802 to 0.841 , further corroborating the significant variation change that occurred around 1990. 


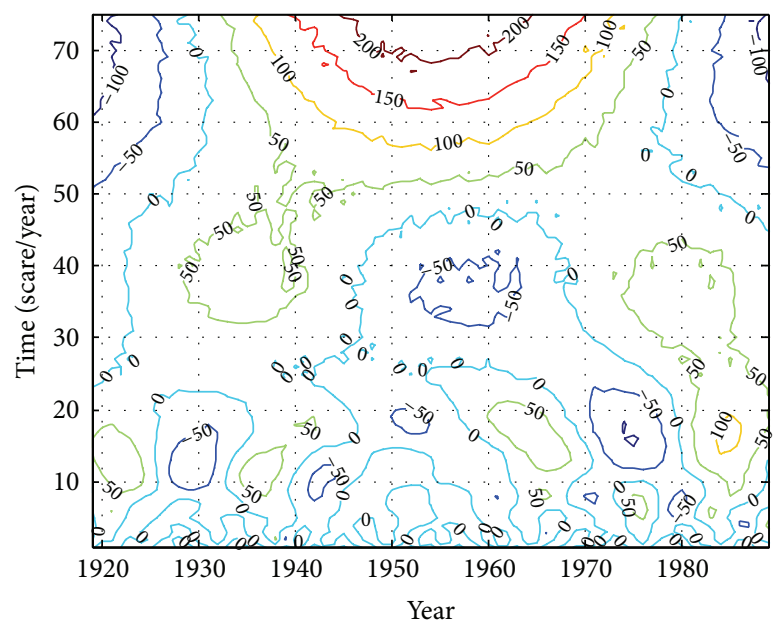

(a) 1919 1989

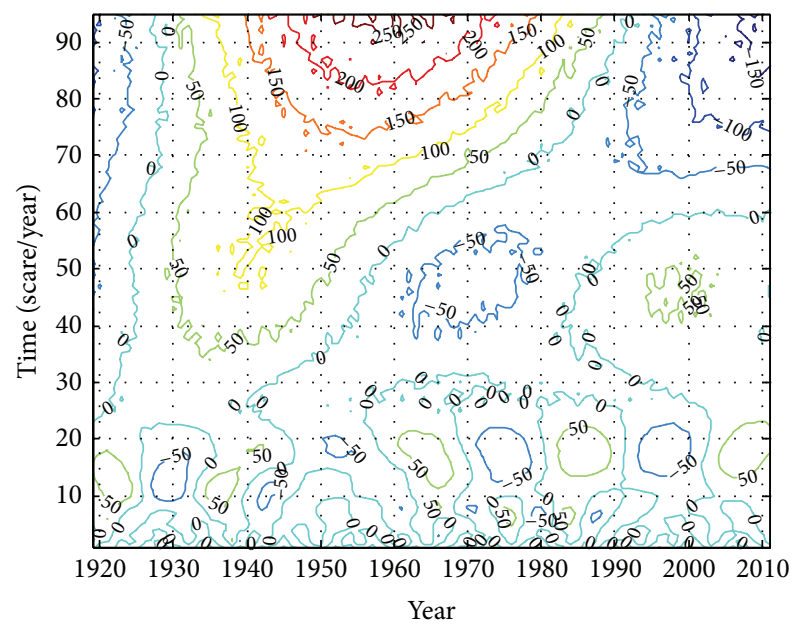

(b) 1919 2011

FIGURE 6: Results of the wavelet variance analysis for runoff periodicity in 1919-1989 and 1919-2011.

TABLE 5: Changes in mean precipitation ( $\mathrm{mm})$ and runoff $\left(10^{8} \mathrm{~m}^{3}\right)$ in the five periods from 1956 to 2011.

\begin{tabular}{lccccccc}
\hline Period & $\begin{array}{c}\text { Mean } \\
\text { precipitation }\end{array}$ & $\begin{array}{c}\text { Mean } \\
\text { change }\end{array}$ & $\begin{array}{c}\text { Percent } \\
\text { change }\end{array}$ & Mean runoff $/\left(10^{8} \mathrm{~m}^{3} / \mathrm{s}\right)$ & Mean change Percent change Specific value $/ 10^{8} \mathrm{~m}^{3}$ Rate changes \\
\hline $1956-1969$ & 594.48 & & & 93.95 & & & \\
$1970-1979$ & 553.8 & -40.67 & $-6.80 \%$ & 59.41 & -40.67 & $-43.30 \%$ & 6.33 \\
$1980-1989$ & 576.09 & -18.39 & $-3.10 \%$ & 79.15 & -14.8 & $-15.80 \%$ & 5.09 \\
$1990-1999$ & 509.46 & -85.02 & $-14.30 \%$ & 43.73 & -50.22 & $-53.50 \%$ & 3.74 \\
$2000-2011$ & 530.83 & -63.65 & $-10.70 \%$ & 49.23 & -44.72 & $-47.60 \%$ & 4.45 \\
\hline
\end{tabular}

TABLE 6: Changes in mean precipitation ( $\mathrm{mm})$ and runoff $\left(10^{8} \mathrm{~m}^{3}\right)$ from $1956-1989$ to $1990-2011$.

\begin{tabular}{lcccccc}
\hline Period & Mean precipitation & Mean change & Percent change & Mean runoff & Specific value $/ 10^{8} \mathrm{~m}^{3}$ & Rate of migration \\
\hline $1956-1989$ & 506.02 & & & 69.04 & & \\
$1990-2011$ & 521.11 & 15.10 & $3.0 \%$ & 46.73 & -22.31 & $-32.3 \%$ \\
\hline
\end{tabular}

4.3. Attribution Analysis. In recent years, there are a lot of studies focusing on the driving factors in hydrological research [33-36]. Climate change and human activities are considered as the main factors driving runoff decline in most of river basins $[6,7]$. In order to evaluate the contribution of these drivers to the changes in runoff in the Weihe River during the study period, the time series is divided into five periods 1956-1969 (baseline), 1970-1979, 1980-1989, 19901999, and 2000-2011.

(1) Contributions of Precipitation. Climate change has an important impact on runoff change $[37,38]$. To assess the contribution of precipitation to the shift in runoff trends, changes of precipitation from baseline (1956-1969) values during subsequent periods are compared to changes of runoff (Table 5). There was a marked decline in both runoff at the Huaxian station and precipitation in the Weihe River basin. However, the relationships differ that precipitation was $6.80 \%, 3.10 \%, 14.30 \%$, and $10.70 \%$ lower in the following periods, while the falls in runoff were $43.30 \%, 15.80 \%, 53.50$, and $47.60 \%$, respectively.

The precipitation and runoff values for the periods before and after the identified variation of 1990 are presented in Table 6. Precipitation in the catchment at the Huaxian station slightly increased, by $3.0 \%$, in the latter period, but runoff volumes fell by $32.3 \%$, confirming the substantial divergence between changes in precipitation and runoff before and after 1990.

(2) Human Water Consumption. Human water consumption in the Weihe River basin significantly increased in the 1990s, especially industrial and domestic water consumption, with rapid increases in groundwater consumption [39]. Total annual consumption increased by $56 \%$ from 2.793 billion $\mathrm{m}^{3}$ (2,383 million $\mathrm{m}^{3}$ of surface water and 410 million $\mathrm{m}^{3}$ of groundwater) before 1990s to 4.263 billion $\mathrm{m}^{3}$ (2.05 billion $\mathrm{m}^{3}$ of surface water and 2.213 billion $\mathrm{m}^{3}$ of groundwater) after 1990s. The increase in water consumption, mainly due 
to a massive rise in exploitation of groundwater, closely correlates with the decrease in runoff carried by the Weihe River (Table 6). Soil and water conservation have an obviously increased, the mean annual runoff have an significantly increased, which is from 116 million $\mathrm{m}^{3}$ (before 10 1990s) upto 300 million $\mathrm{m}^{3}$ (after 1990s). The results clearly indicate that the decline in runoff in the Weihe River basin has been largely driven by human activities rather than climate change, as Yang and Tian [7] found in the Haihe River catchment.

\section{Conclusion}

The results obtained by applying the sequential MannKendall test to a long series of runoff data (1919-2011) collected at the Huaxian station in the Weihe River in the Loess Plateau show that variations occurred in annual, seasonal, and monthly runoff volumes around 1990. This finding is strongly corroborated by the results of wavelet variance analysis, Kendall's rank tests, trend persistence tests, and shifts in skewness coefficients. Attribution analysis indicates that the primary drivers of the shift in runoff volumes were human activities rather than climate change, because water consumption increased sharply in the 1990s but not precipitation.

\section{Acknowledgments}

This work was financially supported by the Natural Science Foundation of China (nos. 51190093, 51179148, 51179149), National Key Basic Research 973 of China (no. 2012CB417003), Governmental Public Industry Research Special Funds for Projects (no. 201101043), and Program for New Century Excellent Talents in University. Constructive comments from reviewers are gratefully acknowledged.

\section{References}

[1] S. Kumar, V. Merwade, J. Kam, and K. Thurner, "Streamflow trends in Indiana: effects of long term persistence, precipitation and subsurface drains," Journal of Hydrology, vol. 374, no. 1-2, pp. 171-183, 2009.

[2] X. Wang, "Editorial: environmental informatics for environmental planning and management," Journal of Environmental Informatics, vol. 9, no. 1, pp. 1-3, 2007.

[3] B. Chen, "Climate change and pesticide loss in watershed systems: a simulation modeling study," Journal of Environmental Informatics, vol. 10, no. 2, pp. 55-67, 2007.

[4] X. S. Qin, G. H. Huang, A. Chakma, X. H. Nie, and Q. G. Lin, "A MCDM-based expert system for climate-change impact assessment and adaptation planning - a case study for the Georgia Basin, Canada," Expert Systems with Applications, vol. 34, no. 3, pp. 2164-2179, 2008.

[5] B. Luo, I. Maqsood, Y. Y. Yin et al., "Adaption to climate change through water trading under uncertainty-an inexact two-stage nonlinear programming approach," Journal of Environmental Informatics, vol. 2, no. 2, pp. 58-68, 2003.

[6] C. J. Vörösmarty, P. Green, J. Salisbury, and R. B. Lammers, "Global water resources: vulnerabilityfrom climate change and population growth," Science, vol. 289, no. 5477, pp. 284-288, 2000.
[7] Y. Yang and F. Tian, "Abrupt change of runoff and its major driving factors in Haihe River Catchment, China," Journal of Hydrology, vol. 374, no. 3-4, pp. 373-383, 2009.

[8] G. Fu, S. Chen, C. Liu, and D. Shepard, "Hydro-climatic trends of the yellow river basin for the last 50 years," Climatic Change, vol. 65, no. 1-2, pp. 149-178, 2004.

[9] Z. Chen, J. Li, H. Shen, and W. Zhanghua, "Yangtze River of China: historical analysis of discharge variability and sediment flux," Geomorphology, vol. 41, no. 2, pp. 77-91, 2001.

[10] H. B. Mann, "Nonparametric tests against trend," Econometrica, vol. 13, no. 3, pp. 245-259, 1945.

[11] M. G. Kendall, Rank Correlation Methods Griffin, London, 1975.

[12] Q. Zhang, C.-Y. Xu, Z. Zhang, Y. D. Chen, C.-L. Liu, and H. Lin, "Spatial and temporal variability of precipitation maxima during 1960-2005 in the Yangtze River basin and possible association with large-scale circulation," Journal of Hydrology, vol. 353, no. 3-4, pp. 215-227, 2008.

[13] M. Sulkava, S. Luyssaert, P. Rautio, I. A. Janssens, and J. Hollmén, "Modeling the effects of varying data quality on trend detection in environmental monitoring," Ecological Informatics, vol. 2, no. 2, pp. 167-176, 2007.

[14] J. Fan, Q. Huang, J. Chang et al., "Detecting abrupt change of streamflow at lintong station of wei river," Mathematical Problems in Engineering, vol. 2013, Article ID 976591, 9 pages, 2013.

[15] W. Fengying, Modern Technology of Statistics, Diagnosis and Forecast For Climate, Meteorological Press, Beijing, China, 2007, Chinese.

[16] K. H. Hamed and A. Ramachandra Rao, "A modified MannKendall trend test for autocorrelated data," Journal of Hydrology, vol. 204, no. 1-4, pp. 182-196, 1998.

[17] Q. Zhang, C. Xu, S. Becker et al., "Sediment and runoff changes in the Yangtze River basin during past 50 years," Journal of Hydrology, vol. 331, no. 3, pp. 511-523, 2006.

[18] A. W. Galli, G. T. Heydt, and P. F. Ribeiro, "Exploring the power of wavelet analysis," IEEE Computer Applications in Power, vol. 9, no. 4, pp. 37-41, 1996.

[19] S. Santoso, E. J. Powers, W. M. Grady, and P. Hofmann, "Power quality assessment via wavelet transform analysis," IEEE Transactions on Power Delivery, vol. 11, no. 2, pp. 924-930, 1996.

[20] P. Pillaya Bhattacharjee, "Application of wavelets to model short-term power system disturbances," IEEE Transactions on Power Systems, vol. 11, no. 4, pp. 2031-2037, 1996.

[21] W. A. Wilkinson and M. D. Cox, "Discrete wavelet analysis of power system transients," IEEE Transactions on Power Systems, vol. 11, no. 4, pp. 2038-2044, 1996.

[22] P. F. Ribeiro, "Wavelet transform: an advanced tool for analyzing non-stationary harmonic distortions in power systems," in Proceedings IEEE International Conference on Harmonics in Power Systems (ICHPS '94), 1994.

[23] R. M. Hirsch, J. R. Slack, and R. A. Smith, "Techniques of trend analysis for monthly water quality data," Water Resources Research, vol. 18, no. 1, pp. 107-121, 1982.

[24] R. M. Hirsch and J. R. Slack, "A nonparametric trend test for seasonal data with serial dependence," Water Resources Research, vol. 20, no. 6, pp. 727-732, 1984.

[25] R. M. Hirsch, R. B. Alexander, and R. A. Smith, "Selection of methods for the detection and estimation of trends in water quality," Water Resources Research, vol. 27, no. 5, pp. 803-813, 1991. 
[26] D. P. Lettenmaier, "Detection of trends in water quality data from records with dependent observations," Water Resources Research, vol. 12, no. 5, pp. 1037-1046, 1976.

[27] D. P. Lettenmaier, E. R. Hooper, C. Wagoner, and K. B. Faris, "Trends in stream quality in the continental United States, 19781987," Water Resources Research, vol. 27, no. 3, pp. 327-339, 1991.

[28] J. Armengol, S. Sabater, A. Vidal et al., "Using the rescaled range analysis for the study of hydrological records: the river Ter as an example," Oecologia Aquatica, vol. 10, no. 10, pp. 21-34, 2012.

[29] P. A. Stott, N. P. Gillett, G. C. Hegerl et al., "Detection and attribution of climate change: a regional perspective," Wiley Interdisciplinary Reviews: Climate Change, vol. 1, no. 2, pp. 192211, 2010.

[30] R. Sneyers, Sur Lanalyse Statistique Des Series Dobser6ations, Tech. Note, Geneva, Switzerland, 1975.

[31] F.-W. Gerstengarbe and P. C. Werner, "Estimation of the beginning and end of recurrent events within a climate regime," Climate Research, vol. 11, no. 2, pp. 97-107, 1999.

[32] C. Bai and S. Zhang, "Detection of the variation points of Weihe River watershed runoff process based on rank sum," Journal of Northwest A\&F University, vol. 37, no. 10, pp. 215-220, 2009.

[33] N. W. Arnell, "Climate change and global water resources," Global Environmental Change, vol. 9, pp. S31-S49, 1999.

[34] D. Labat, Y. Goddéris, J. L. Probst, and J. L. Guyot, "Evidence for global runoff increase related to climate warming," Advances in Water Resources, vol. 27, no. 6, pp. 631-642, 2004.

[35] C. d. Fraiture, "Integrated water and food analysis at the global and basin level. An application of WATERSIM," Water Resources Management, vol. 21, no. 1, pp. 185-198, 2007.

[36] M. I. Hejazi and G. E. Moglen, "Regression-based approach to low prediction in the Maryland Piedmont region under joint climate and land use change," Hydrological Processes, vol. 21, no. 14, pp. 1793-1801, 2007.

[37] V. K. Arora, "The use of the aridity index to assess climate change effect on annual runoff," Journal of Hydrology, vol. 265, no. 1-4, pp. 164-177, 2002.

[38] C. M. Liu and J. Xia, Global Water System Project, 2004.

[39] X. L. Su, S. Z. Kang, X. M. Wei et al., "Impact of climate change and human activity on the runoff of Wei River basin to the Yellow River," Journal of Northwest A \& F University, vol. 2, p. 32, 2007. 


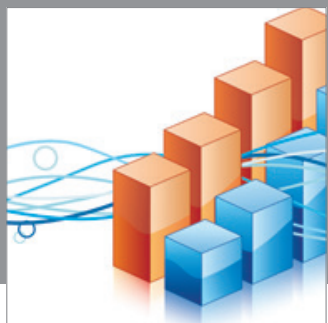

Advances in

Operations Research

mansans

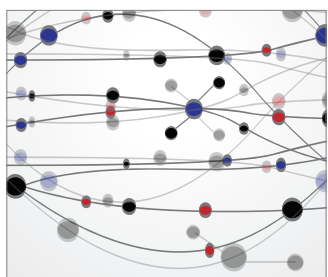

The Scientific World Journal
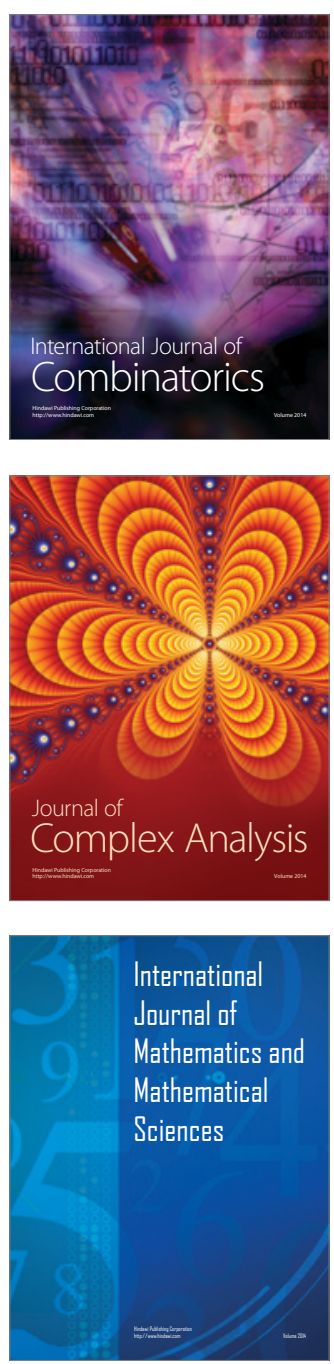
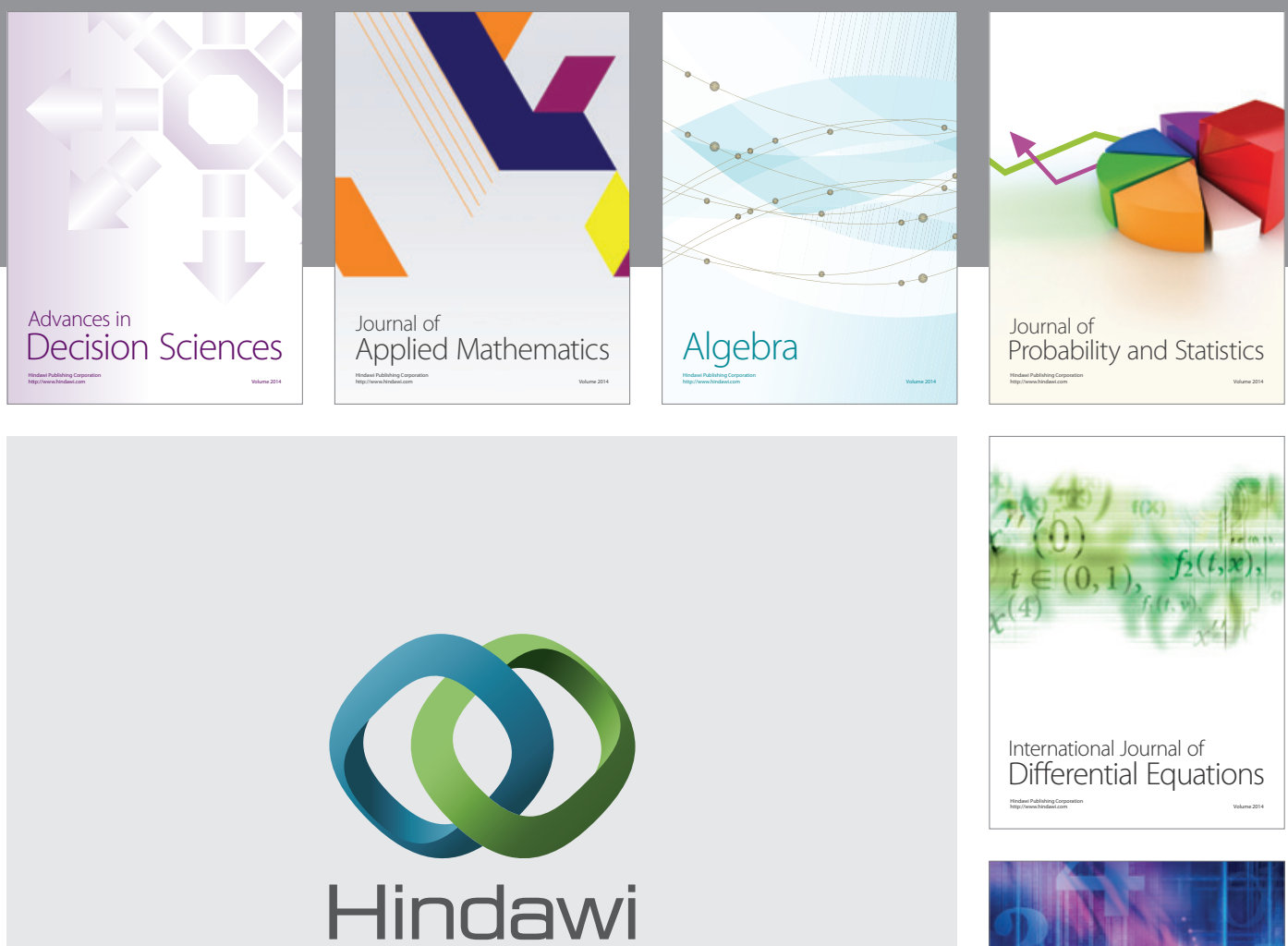

Submit your manuscripts at http://www.hindawi.com
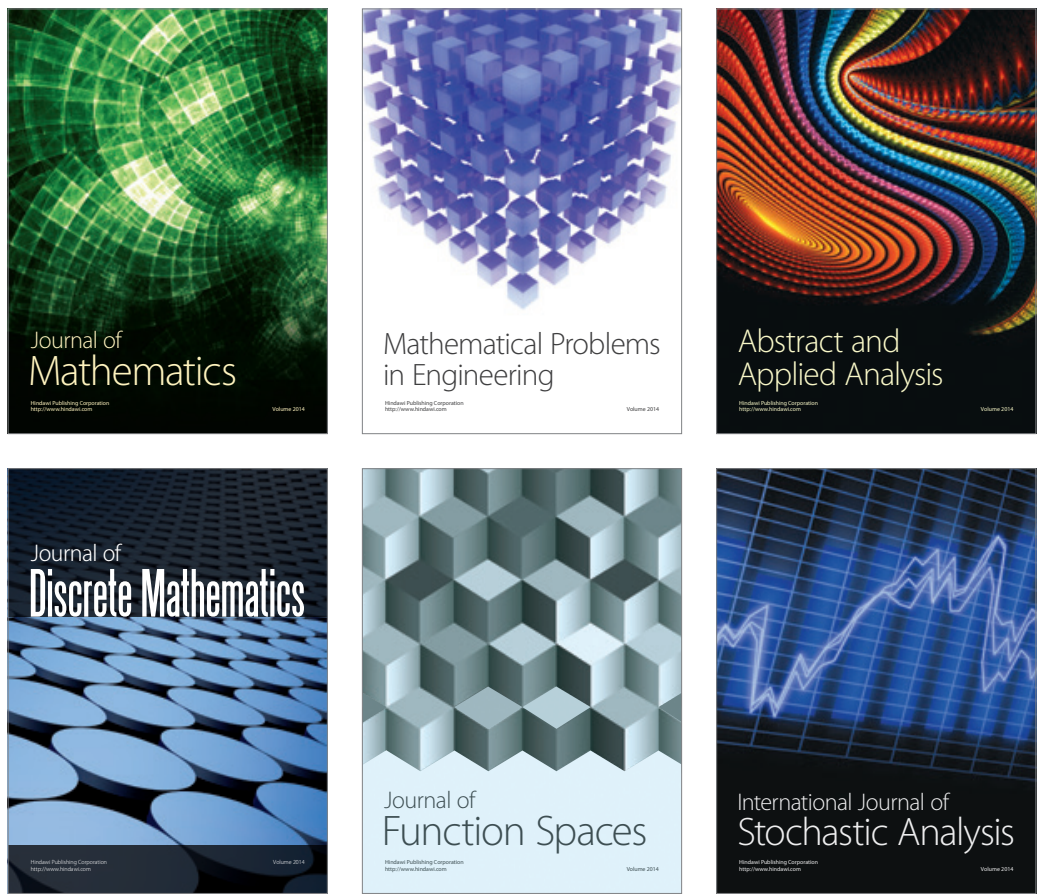

Journal of

Function Spaces

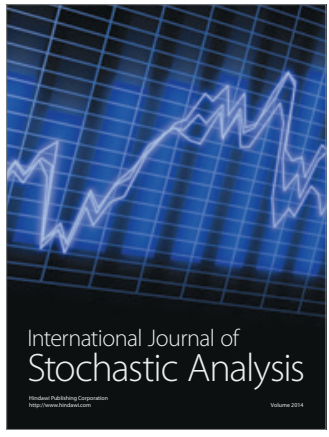

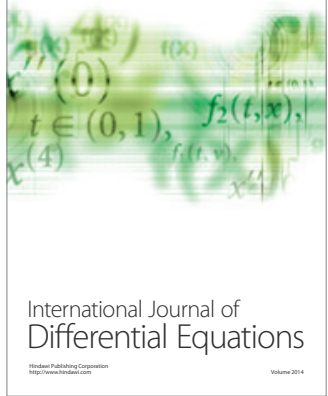
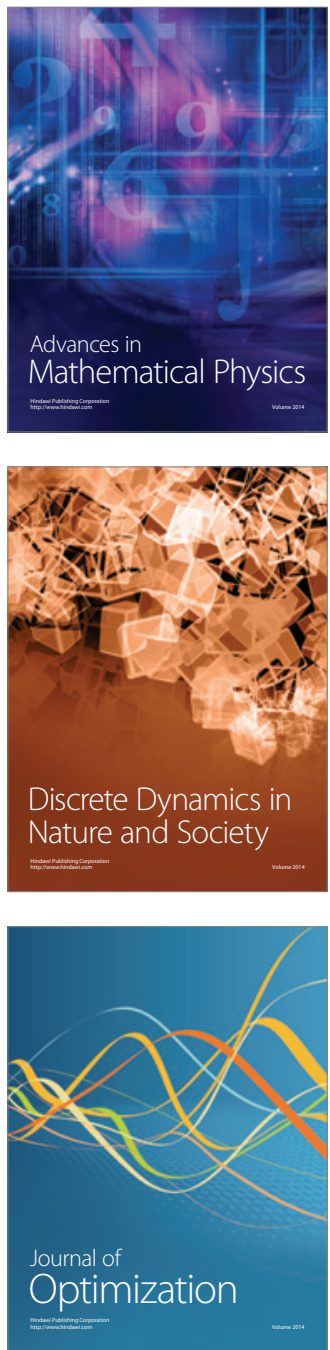